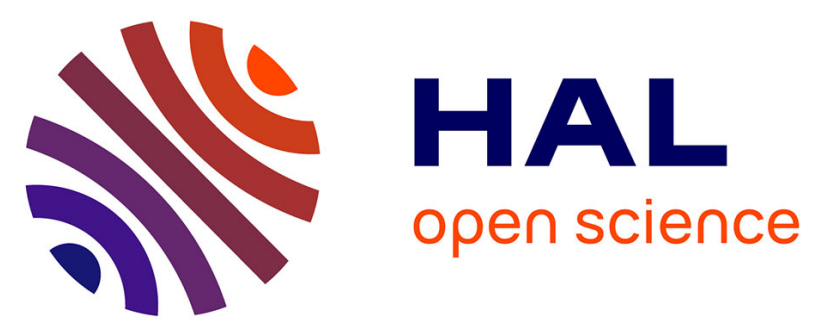

\title{
Surface expression of metabotropic glutamate receptor variants mGluR1a and mGluR1b in transfected HEK293 cells.
}

Jiri Kumpost, Zdenka Syrova, Lenka Kulihova, Daniela Frankova, Jean-Charles Bologna, Veronika Hlavackova, Laurent Prézeau, Michaela Kralikova, Bohdana Hruskova, Jean-Philippe Pin, et al.

\section{To cite this version:}

Jiri Kumpost, Zdenka Syrova, Lenka Kulihova, Daniela Frankova, Jean-Charles Bologna, et al.. Surface expression of metabotropic glutamate receptor variants mGluR1a and mGluR1b in transfected HEK293 cells.. Neuropharmacology, 2008, 55 (4), pp.409-18. 10.1016/j.neuropharm.2008.06.073 . inserm-00319023

\section{HAL Id: inserm-00319023 https://www.hal.inserm.fr/inserm-00319023}

Submitted on 5 Sep 2008

HAL is a multi-disciplinary open access archive for the deposit and dissemination of scientific research documents, whether they are published or not. The documents may come from teaching and research institutions in France or abroad, or from public or private research centers.
L'archive ouverte pluridisciplinaire HAL, est destinée au dépôt et à la diffusion de documents scientifiques de niveau recherche, publiés ou non, émanant des établissements d'enseignement et de recherche français ou étrangers, des laboratoires publics ou privés. 
Surface Expression of Metabotropic Glutamate Receptor Variants mGluR1a and mGluR1b in Transfected HEK293 cells

Zdenka Syrova ${ }^{\mathrm{a}, \mathrm{g}}$, Lenka Kulihova ${ }^{\mathrm{a}, \mathrm{g}}$, Daniela Frankova ${ }^{\mathrm{a}}$, Jiri Kumpost ${ }^{\mathrm{a}}$, Veronika Hlavackova ${ }^{\mathrm{c}}$, Laurent Preseau ${ }^{\mathrm{b}}$, Michaela Havlickova ${ }^{\mathrm{d}}$, Bohdana Hruskova ${ }^{\mathrm{e}}$, Jean-Philippe Pin ${ }^{\mathrm{b}}$ and Jaroslav Blahos ${ }^{\text {a,f }}$

${ }^{a}$ Institute of Molecular Genetics, Academy of Sciences of the Czech Republic and Departement of Pharmacology, 2nd Medical School, Charles University, Prague, Czech Republic

${ }^{\mathrm{b}}$ Institut de Génomique Fonctionnelle, Centre National de la Recherche Scientifique Unité Mixte de Recherche 5203, Institut National de la Santé et de la Recherche Médicale, U661, and Université de Montpellier (IFR3), Montpellier, France

Present address:

${ }^{\mathrm{c}}$ Inst. für Pharmakologie, Versbacherstrasse 9, 97078 Würzburg, Germany

${ }^{\mathrm{d}}$ Columbia University P\&S 11-401 630 West 168th Street New York, NY 10032, U.S.A.

${ }^{\mathrm{e}}$ Institute of Experimental Medicine ASCR, Prague, Czech Republic

${ }^{\mathrm{f}}$ To whom correspondence should be addressed:

Jaroslav Blahos, Institute of Molecular Genetics AS CR, Videnska 1083, 14220 Prague 4, Czech

Republic.e-mail: blahos@img.cas.cz

${ }^{\mathrm{g}}$ These authors contributed equally to the manuscript

Keywords: Metabotropic glutamate receptors, G-protein Coupled Receptors, trafficking, dimerization 


\section{Abstract}

Class C G-protein coupled receptors form obligatory dimers. Metabotropic glutamate receptors (mGluRs) are found commonly as homodimers. Alternative splicing of mGluR1 gene results in vivo at long variant mGluR1a and short variants mGluR1b, $\mathrm{c}$ and $\mathrm{d}$. The amino acid sequences diverge within their Carboxyl-termini six amino acid residues following RRKK motif. This four basic residue sequence was shown to have pronounced impact on function and trafficking of the short variants, while for mGluR1a the long C-terminus reduces the effects caused by presence of the RRKK motif. Here we investigated consequences of interactions between long mGluR1a and short mGluR1b variants. Our results show, that mGluR1a interferes with mGluR1b trafficking to the cell surface in HEK293 transfected cells. Moreover, we show that swapping long mGluR1a and/or short mGluR1b C-termini with corresponding regions in chimerical GB1 and GB2 $\gamma$-amino butyric acid b (GABAb) receptor subunits does not exclude their heterodimerization.

\section{Introduction}

Intracellular carboxyl-terminal domains (C-tails) of G-protein coupled receptors (GPCRs) possess multiple sites for the interaction of various types of intracellular proteins. These interactions control proper targeting of the receptors and their association with signaling cascade molecules (Bockaert et al., 2003). In addition, the C-tails are the target of post translational modifications that play important role in desensitization and internalization of these heptahelical receptors (for review see (Kim et al., 2008)).

Several metabotropic glutamate receptors exhibit alternative splicing in their carboxyl-termini (Pin and Duvoisin, 1995). Splicing of rat metabotropic glutamate receptor 1 (mGluR1) gene results in expression of at least three variants, the long mGluR1a and short forms mGluR1b and $\mathrm{d}$. These variants share the same sequence up to position 886; then followed by 313 residues in mGluR1a, 20 in mGluR1b and 26 in 1d. All carry a four basic amino acid sequence (RRKK) in their common sequence, 6 residues upstream of the splice site. This RRKK sequence falls into a group of di-lysine motives that are recognized by the coat protein I complex (COPI). This interaction controls protein 
trafficking at specific intracellular checkpoints, namely retrieval from cis-Golgi to endoplasmic reticulum (ER) (Brock et al., 2005). For the release from the ER, this sequence has to be neutralized by interactions with other proteins or by sequences positioned on its own polypeptide chain. Such mechanism of neutralization of the RRKK motif by sequence from its own polypeptide chain was proposed for the long tail of mGluR1a (Ciruela et al., 1999; Mary et al., 1998; Mundell et al., 2004; Remelli et al., 2008), based on data obtained both in transfected cells and in neurons. Indeed, the RRKK motif has pronounced effect on the cell surface targeting and limits specific signaling properties of the short variants only (Das and Banker, 2006; Francesconi and Duvoisin, 2002; Mary et al., 1998; Pin et al., 1994; Pin et al., 1992; Prezeau et al., 1996). However, it is not clear, whether the neutralizing effect observed in mGluRla is caused solely by the extended C-tail, or by another protein that interacts with it.

The mGlu receptors are mandatory dimers detected in the brain as homodimers (Romano et al., 1996). Here we examined whether mGluR1a and mGluR1b associate in heterodimeric entities, and if such relation would change their properties. In other words, would the specific properties of this heterodimer be similar to those of mGluR1a or mGluR1b homodimers, or even different?

Here we show that the long C-terminal tail of mGluR1a is sufficient not only to prevent the action of the RRKK motif of it own C-tail, but also that of an associated mGluR1b, such that the heterodimer nicely reach the cell surface, and function like a mGluR1a homodimer. In cells co-expressing both variants we found strong co-localization at the cell surface. Moreover, the long C-terminus of the mGluR1a had chaperone effect on mGluR1b subunit that resulted in markedly higher surface expression of mGluR1b. 


\section{Materials and methods}

Chemicals including glutamate were obtained from Sigma-Aldrich (Czech Republic) unless otherwise indicated. Serum, culture media and other solutions used for cell culture were from (Gibco BRL, Czech Republic).

2.1.Mutagenesis Constructs HA-mGluR1 and HA-GB1a and HA-GB2 were used and described in our previous studies (Ango et al., 2000; Galvez et al., 2001; Havlickova et al., 2003; Hlavackova et al., 2005; Pagano et al., 2001). MGluR1b variant was tagged using the same strategy. Shortly, tags HA (hemagglutinin) or c-Myc were introduced in the extreme N-terminal part of the receptor preceded by a signal peptide sequence derived from mGluR5. Mature mGluR1a or mGluR1b (coding sequence starting at Serine 34) were introduced by unique MluI restriction side located after the tag coding sequence. The expressed recombinant receptors thus consist of the signal peptide sequence of mGluR5, HA or c-Myc epitopes followed by mGluR1a or mGluR1b sequence. Mutation F781P was introduced in the i3 loop of HA-mGluR1a as described (Hlavackova et al., 2005) and the YADA (Y226A and D318A) mutations were done in mGluR1 in same manner as described previously for mGluR5 (Kniazeff et al., 2004) using QuickChange site-directed mutagenesis kit (Stratagene, Chemos, Czech Republic). The chimerical proteins $\mathrm{GB} / \mathrm{C} 1$ consisting of the N-terminal and heptahelical domains of the GABAb receptor GB1a or GB2 subunits followed by the carboxyl-termini of mGluR1a or mGluR1b variants were done using unique Sph1 site on mGluR1 receptor DNA positioned within the portion identical between all the mGluR1 variants. Sph1 site was engineered in the GB1 (after Asp 873) and GB2 (after Arg 759) sequences. Substitution of the carboxyl terminal part were done using Sph1-Xba1 sites for mGluR1a (His 859-Stop 1200) or mGluR1b (His 859-Stop 907) coding sequences. To allow detection of the recombinant receptors on cell surface the N-terminal 16 residues of rat GB1a and N-terminal 41 residues of rat GB2 were replaced by 36 residues encoding the mGluR5 signal peptide, and HA epitope. The adaptor Gqi9 protein, based on sequence of Gq with last 9 residues replaced by extreme $\mathrm{C}$ terminal 9 residues from Gi sequence was described (Conklin et al., 1993) and used previously in our studies (Franek et al., 1999; Galvez et al., 2001; Havlickova et al., 2003). All constructs were sequenced using Big Dye Terminater v. 3,1 Cycle Sequencing Kit (Applied Biosystems, Foster City, CA).

2.2. Cell culture and transfection Human embryonic kidney cells (HEK293) were cultured in Dulbecco's modified Eagle's medium (DMEM), without sodium pyruvate and supplemented with $10 \%$ fetal calf serum, penicillin and streptomycin $(100 \mathrm{U} / \mathrm{ml}$ final). Electroporation was performed by ECM 399 Pulse Generator (BTX Division of Genetronies, San Diego, USA) in the condition, $3.2 \times 10^{6}$ cells in total volume of $800 \mu 1$ DMEM with $2 \mu \mathrm{g}$ of each tested DNA and total amount was brought up to $10 \mu \mathrm{g}$ with carrier DNA (pRK6), and $270 \mathrm{~V}$. After electroporation, cells were resuspended in 
DMEM supplemented with $10 \%$ fetal calf serum and antibiotics, and seeded on $96-$ well plates (Nunc $^{\mathrm{TM}}$, Shoeller Pharma, Czech Republic) for ELISA, or on poly-L-ornithin coated coverslipes for the functional assay and immunocytochemistry. Media were changed 6 hours later to glutamate-free medium Glutamax and the cells were incubated for another 18 hours.

2.3. ELISA Cell surface expression levels of the HA- and cMyc-tagged receptors were determined using ELISA assay as described (Brock et al., 2005). Transfected or mock cells were fixed with 4\% paraformaldehyde, blocked $30 \mathrm{~min}$ with $1 \%$ FBS in PBS and incubated for 30 min with mouse monoclonal anti-HA antibody conjugated to horseradish peroxidase (Roche Diagnostics, Czech Republic) diluted 1:2000 or mouse monoclonal anti-cMyc antibody (kindly provided by Dr. V. Korinek ) in 1:4000 dilution. C-Myc labeling continued after several washing steps by incubation with secondary goat anti-mouse antibodies conjugated to horseradish peroxidase (Santa Cruz Biotechnology, Czech Republic) in 1:1000 dilutions for 30 minutes. Super-Signal ${ }^{\circledR}$ ELISA pico chemiluminescent substrate (Pierce, Biotech, Czech Republic) generated chemiluminescence was quantified using luminescence counter Envision 2103 Multilabel Reader (Perkin-Elmer, Czech Republic). Student's $t$ test was used for statistical analysis of ELISA. Values of $P<0.05$ were considered to represent statistically significant differences.

2.4. Calcium imaging 24 hour after transfection the cells were washed with HEPES-buffered Hank's Balanced Salt Solution containing $1 \mathrm{mM} \mathrm{MgSO} 4,3.3 \mathrm{mM} \mathrm{Na}_{2} \mathrm{CO}_{3}, 1.3 \mathrm{mM} \mathrm{CaCl}_{2}, 1 \%$ BSA, $2.5 \mathrm{mM}$ probenecid, with $\mathrm{pH} 7.4$ (HBSS) and incubated with $1 \mu \mathrm{M} \mathrm{Ca}^{2+}$ sensitive fluorescent dye Fluo-4 AM (Molecular Probe, Leiden, Netherlands), $0.5 \mu \mathrm{M}$ pluronique acid (Interchim S.A. Montlucon, France), GPT $(10 \mathrm{U} / \mathrm{ml})$ and $2 \mathrm{mM}$ pyruvate for $1 \mathrm{~h}$ at $37^{\circ} \mathrm{C}$ and washed after with $\mathrm{HBSS}$. $\mathrm{Ca}^{2+}$ responses were recorded by inverted microscope IX81 (Olympus) equipped with digital CCD camera (C4742-8012AG, Hamamatsu Photonics K.K, Japan), using 460-480 excitation filter and 495-540 emission filter. Images were captured at 1 second intervals for 3 minutes. Agonist $(10 \mathrm{mM})$ quisqualate (Tocris Cookson Ltd., Bristol, U.K.) was added $10 \mathrm{~s}$ after start of the recording. The responses of cells were analyzed using CellR' software (Olympus) and the results were plotted as ration of the Fluorescence emmision $(\mathrm{F})$ divided by the initial unstimulated fluorescence $\left(\mathrm{F}_{0}\right)$, and quantified using GraphPad Prism (GraphPad Software, San Diego, CA, U.S.A.). Cells transfected with pRK6 DNA were used as controls (data not shown).

2.5. Inositol Phosphates Accumulation assay The procedure used for the determination of Inositol Phosphates (IP) accumulation in transfected cells was adapted from previously published methods (Berridge, 1983 Bone, 1984) for 96 well plate format as described (Goudet et all 2004). Briefly, cells 
were washed 2 to 3 hours after electroporation and incubated for 14 hours in DMEM-glutamax-I (Gibco, Paris, France) containing $1 \mu \mathrm{Ci} / \mathrm{ml}\left[{ }^{3} \mathrm{H}\right]$-myo-inositol (23.4 Ci/mol), (NEN, Paris, France). Cells were then washed 3 times and incubated for $1-2$ hours at $37^{\circ} \mathrm{C}$ in $1 \mathrm{ml}$ Hepes buffer saline $(\mathrm{NaCl}$ $146 \mathrm{mM}, \mathrm{KCl} 4.2 \mathrm{mM}, \mathrm{MgCl}_{2} 0.5 \mathrm{mM}$, Glucose $0.1 \%$, Hepes $20 \mathrm{mM} / \mathrm{pH}$ 7.4) supplemented with $1 \mathrm{U} / \mathrm{ml}$ Glutamate pyruvate transaminase (Boehringer Mannheim, Meylan, France) and $2 \mathrm{mM}$ pyruvate (Sigma, Lisle d'Abeau, France). Cells were then washed again twice with the same buffer and LiCl was added to a final concentration of $10 \mathrm{mM}$. The agonist was applied 5 min later and left for $30 \mathrm{~min}$. The reaction was stopped with 0,1 M formic acid. IP produced were purified in 96-well plates by ionexchange chromatography. Radioactivity was measured using a Wallac 1450 MicroBeta microplate liquid scintillation counter (Molecular Devices, U.S.A.). Results are expressed as the amount of IP produced over the radioactivity present in the membranes.

2.6. Immunocytochemistry Cells were used 24 hours after transfection as in previous experiments. Cells were washed in phosphate-buffer saline (PBS) and fixed with $4 \%$ pharaformaldehyde (EMS, Hatfield, USA) in PBS for $10 \mathrm{~min}$ at $20^{\circ} \mathrm{C}$. The fixed cells were washed in PBS and 10 minutes permeabilized with 0,05\% Triton X-114 (Serva, Biotech, Czech Republic). After 10 minutes incubation in $1 \%$ BSA in PBS (blocking buffer) cells were incubated with primary antibody for 2 hours at $20^{\circ} \mathrm{C}$, washed in blocking buffer briefly and incubated with secondary antibody for 2 hours at $20^{\circ} \mathrm{C}$ in dark. Further, cells were washed repeatedly in blocking buffer, once in PBS and mounted on microscope slides in Mowiol (Calbiochem, Germany) and sealed with a nail varnish. The images were taken using Leica TCS SP5 confocal scanning microscope.

Primary antibodies were used in dilutions: monoclonal mouse anti-HA (Santa Cruz, US.A.) 1:200, polyclonal rabbit anti-HA (Santa Cruz, U.S.A.) 1:200, monoclonal mouse anti-cMyc. Novel sera N14 (rabbit) raised against synthetic peptides linked to thyreoglobulin (mGluR1a derived epitope CTPPNVTYASVILRDYKQSSSTL-COOH) and O13 (guinea pig) generated against epitope derived from mGluR1b sequence (KRQPEFSPSSQCPSAHAQL-COOH) were used in dilution 1:500 (Mateos et al., 1998; Petralia et al., 1997; Shigemoto et al., 1996). Secondary antibodies were used in dilutions: anti-mouse FITC-conjugated 1:100, anti-rabbit FITC-conjugated 1:100, anti-rabbit Cy3-conjugated 1:300, anti-guinea pig Cy3-conjugated 1:300, anti-mouse Cy3-conjugated 1:300, all secondary antibodies were from Jackson ImmunoReseach (U.S.A.).

2.7. Immunoblotting The amounts of the expressed proteins were determined by Western-blot analysis. HEK293 cells were cultured in $6 \mathrm{~cm}$ Petri dishes overnight after transfection. After washing, cells were harvested and sonicated at $4^{\circ} \mathrm{C}$ in sample buffer (0.1 M Trizma- Base, $\left.0.1 \mathrm{M} \mathrm{NaCl}, \mathrm{pH} 7.4\right)$, and heated at $80^{\circ} \mathrm{C}$ for $15 \mathrm{~min}$ in treatment buffer $(62,5 \mathrm{mM}$ Trizma-Base, $2 \%$ Sodium-dodecyl sulfate (SDS), 10\% glycerol, $190 \mathrm{mM}$ Dithiothreitol (DTT), 0,01\% bromophenol blue). Western blot analyses 
were carried out using $10 \%$ gels of total acrylamide in Tris/Tricine/SDS-PAGE system or in Tris/Glycine/SDS-PAGE (Laemmli, 1970; Schagger and von Jagow, 1987) and blotted onto nitrocellulose membrane. The membranes were blocked overnight in $4 \%$ non-fat dried milk solution in PBS. The antibodies were used as described above, except for different dilutions. Primary antibodies were used in 1:250 diltutions and crude sera in 1:5000 dilutions. After $4 \mathrm{~h}$ incubation in $20^{\circ} \mathrm{C}$ the corresponding secondary antibodies labeled with horse radish peroxidase (HRP) for detection were used according to manufactures instructions and signals were developed using Super-Signal ${ }^{\circledR}$ ELISA Pico chemiluminescent substrate (Pierce, Biotech, Czech Republic). For immunoblots following the immunoprecipitations $4-20 \%$ continuous gradient SDS-PAGE gels were used for better separation of the homodimeric and heterodimeric mGluR1 complexes. To avoid cross reactivity of the immunoprecipitation and the staining secondary antibodies Anti-HA-Peroxidase, High Affinity antibodies (3F10) (Roche Applied Science, Czech Republic) were employed.

2.8. Immunoprecipitation HEK293 cells were cultured in $6 \mathrm{~cm}$ Petri dishes overnight after transfection. After washing at $4^{\circ} \mathrm{C}$ with $0.1 \%$ BSA in PBS, for detergent solubilization $1 \mathrm{ml}$ of $0.1 \%$ Nonidet P-40 (Sigma-Aldrich, Czech republic) was used in 0.1 M Trizma- Base, 0.1 M NaCl, pH 7.4 for $30 \mathrm{~min}$. The supernatants were collected without disturbing insoluble debris and diluted 10x with the same buffer without additional detergent and all samples were treated with NEM (N-ethyl maleimide, Pierce, Biotech, Czech Republic) in final concentration of $10 \mathrm{mM}$ at for $30 \mathrm{~min} 4^{\circ} \mathrm{C}$. The samples were centrifuge for $1 \mathrm{hr}$ at $100,000 \times \mathrm{xg}, 4^{\circ} \mathrm{C}$ and $1 \mathrm{ml}$ of the soluble fractions were incubated with $2 \mu 1$ of the crude sera overnight. The antibodies were incubated with $20 \mu 1$ of Immobilized Protein A on agarose beads (ImmunoPure, Pierce, Biotech, Czech Republic), pulled down and treated in 100 $\mu 1$ SDS-PAGE sample buffer $80^{\circ} \mathrm{C}$ for $10 \mathrm{~min}$ and $10 \mu \mathrm{l}$ were loaded on gels for immunoblot analysis.

2.9. HTR-FRET Experiments were performed as previously described (Maurel et al., 2004). Briefly, HEK293 cells expressing the indicated HA- or Myc-tagged receptor subunits were labeled with monoclonal anti-HA (12CA5) and/or anti-Myc (9E10; American Type Culture Collection no. CRL1729) carrying either $\mathrm{Eu}^{3+}$ Cryptate pyridine-bipyridine or AlexaFluor 647 (provided by Cis Bio International Research). Fluorescence of $\mathrm{Eu}^{3+}$ Cryptate and TR-FRET signal were measured $50 \mu \mathrm{s}$ after excitation with $337 \mathrm{~nm}$ at 620 and $665 \mathrm{~nm}$ respectively, using a RubyStar fluorimeter (BMG Labtechnologies, Champigny-sur-Marne, France). In parallel, the total fluorescence emitted at $682 \mathrm{~nm}$ by the bound Alexa647 antibodies was quantified after excitation at 640 using an Analyst ${ }^{\mathrm{TM}}$ reader (Molecular Devices). The FRET signal was measured as $\Delta \mathrm{R}$ using the following equation: $\Delta \mathrm{R}=\left[(\mathrm{R} 665 / 620)_{\mathrm{POS}}-(\mathrm{R} 665 / 620)_{\mathrm{NEG}}\right]$ where $(\mathrm{R} 665 / 620)_{\mathrm{POS}}$ is the ratio of the $665 \mathrm{~nm}$ signal over that at $620 \mathrm{~nm}$ measured in the presence of both antibodies, and (R665/620) $)_{\mathrm{NEG}}$ is the same ratio measured in the absence of the acceptor-labeled antibody. 


\section{Results}

The mGluR1a and mGluR1b receptors were N-terminally tagged with hemagglutinin (HA) or C-Myc for detection at the cell surface. We previously reported that the insertion of these tags after the signal peptide, and before the Venus fly trap (VFT) ligand binding domain does not alter functional properties of class C GPCRs (both mGlu and GABAb receptors) (Ango et al., 2000; Galvez et al., 2001; Havlickova et al., 2002; Hlavackova et al., 2005; Pagano et al., 2001). We used wild type receptors where possible in order to verify results obtained with our N-terminally tagged proteins. In the functional assays and in immunohistochemical detections of the variants in transfected cells the results obtained using the wild type receptors or the tagged proteins were fully comparable (data not shown).

The surface expression of HA-mGluR1a was clearly visible on non-permeabilised cells $24 \mathrm{~h}$ after transfection. Expression of HA-mGluR1b or Myc-mGluR1b was also apparent, but with lower intensity than that of HA-mGluR1a (Fig.1). The cell surface Myc-mGluR1b labeling intensity augmented considerably upon co-expression with mGluR1a. Staining of permeabilised cells with corresponding antibodies to both subunits revealed their large intracellular pools. We also employed our polyclonal antibodies directed against the C-termini that distinguish between the mGluR1a and mGluR1b variants (Fig. 2). To characterize the novel antibodies we expressed tagged proteins and compared staining obtained with the anti-tag antibodies with staining of the novel subunit specific antibodies. The patterns did overlap proving the specificity of the rabbit antibodies N14 and guinea pig O13 (Fig. 2a). In next experiment we used wild type receptors for co-transfections. Staining of the wild-type mGluR1a and mGluR1b subunits in permeabilised cells resemble results using the tag detection (Figs. 1b and 2b). We did not analyze non-permeabilised cells with our antibodies as these are directed against epitopes corresponding to extreme carboxyl-termini of the variants (amino acid residues 1177-1199 of mGluR1a for N14 and residues 888-906 of mGluR1b for O13 antibodies).

Expression of HA-mGluR1a and HA-mGluR1b alone led to well detectable signals in ELISA performed on intact cells. HA-mGluR1a alone was assigned arbitrarily as $100 \%$. The signal detected on cells expressing HA-mGluR1b was $48 \pm 12 \%$ of that for HA-mGluR1a. The HA signal detected at the cell surface of cells that co-express HA-mGluR1b with HA-mGluR1a was $149 \pm 33 \%$ (Fig. 3a). Next we measured ELISA signals for HA-mGluR1a and Myc-mGluR1b either expressed alone or in combination. C-Myc signal detected on intact cells upon expression of Myc-mGluRlb alone and the HA signal for HA-mGluR1a were assigned arbitrarily as 100\%. The C-Myc signal detected at the cell surface of cells that co-express Myc-mGluR1b with HA-mGluR1a was $296 \pm 58 \%$ compared to the signal detected on cells expressing Myc-mGluR1b only (Fig. 3b). The amount of cell-surface labeling 
of HA-mGluR1a did not change notably when expressed alone or with mGluR1b. The experiments show that targeting of mGluR1b to the cell surface is enhanced upon co-expression with mGluR1a.

The expression levels of HA-mGluR1a were not significantly influenced in experiment in which increasing amounts of cDNA of mGluR1b were used for co-transfections. In this case the higher levels of total Myc-mGluR1b protein were reflected by higher cell surface targeting of the mGluR1b subunit co-expressed with mGluR1a (Fig. 3c).

In order to firmly demonstrate mGluR1a-mGluR1b heterodimers exist at the cell surface, TR-FRET experiments were performed with an anti-HA antibody labeled with the donor fluorophore $\mathrm{Eu}^{3+}$ Cryptate, and an anti-myc antibody labeled with the acceptor fluorophore Alexa647 (Maurel et al., 2004). We co-transfected HA-mGluR1a with constant and Myc-mGluR1b with increasing amounts of cDNA and monitored emission of the energy transfer between the fluorophores on intact cells. In cells co-transfected with HA-mGluR1a and Myc-mGluR1b a significant FRET signal was observed (Fig. 4). The FRET signal (delta665) was directly proportional to the amount of Myc-mGluR1b cDNA used for transfection. No significant signal was detected in cells expressing HA-mGluR1a and Myc-GB2 (subunit of GABAb receptor). This demonstrates the specificity of the signal observed.

Next we compared total protein amounts of these variants in cells expressing either of each variant alone and in combination. On immunoblots of SDS-PAGE separated proteins we detected the mGluR1 variants with our novel polyclonal antibodies. Protein amounts detected for each variant in protein extracts from cells transfected singly were comparable with corresponding protein amounts in cells cotransfected with both mGluR1a and mGluR1b. Increase of cell surface trafficking of mGluR1b upon co-expression with mGluR1a is therefore not caused by variation of total protein expression (Fig. 5). Moreover, on the immunoblots we and others repeatedly reported appearance of two bands for each variant, the faster being the monomer form of the receptor and the slow migrating protein complex being assumed dimeric protein resistant to reduction agents and SDS treatment. In case of mGluR1a and mGluR1b co-expression, using anti-mGluR1a or anti-mGluR1b specific antibodies we noticed another band in the range of the slow migrating component which may correspond to heterodimeric mGluR1a-mGluR1b treatment resistant complexes (for detail see Fig. 5b). Because the intensities of the slow migrating bands vary significantly between experiments and this may be caused by many factors, including the sample treatment, we did not attempt to quantify this phenomenon.

We employed the mGluR1b splice variant specific antibodies $\mathrm{O} 13$ for immunoprecipitation of the detergent-soluble receptors from cells transfected with the HA-mGluR1a and Myc-mGluR1b (samples labeled AB in Fig. 5c). As a control we used cells transfected with the mGluR1 splice variants coding vectors separately (labeled $\mathrm{A}+\mathrm{B}$ in Fig. 5c). In this case we mixed the detergent soluble fractions after the NEM treatment and carried out the precipitation in parallel with the samples from co-transfected cells. The antibodies immunoprecipitated Myc-mGluR1b from samples prepared from both, the AB co-transfected cells samples and the $\mathrm{A}+\mathrm{B}$ sample. HA-mGluR1a co-precipitated only from the detergent soluble fraction from $\mathrm{AB}$ sample and was found in the unbound fraction of the control $\mathrm{A}+\mathrm{B}$ 
samples. The velocities of the presumed dimeric form of the splice variant on SDS-PAGE were different for the HA-mGluR1a homodimer, Myc-mGluR1b homodimer and HA-mGluR1a-MycmGluR1b heterodimer and did correspond to the theoretical sizes of the complexes (Fig. 5c.).

Next we measured functional responses using intracellular $\mathrm{Ca}^{2+}$ mobility assay in cells transfected with mGluR1a or mGluR1b, alone or in combination. Application of $10 \mu \mathrm{M}$ quisqualate on mGluR1a expressing cells resulted in transiently elevated $\mathrm{Ca}^{2+}$ levels with consistent pattern. Activation of the short variant mGluR1b resulted in $\mathrm{Ca}^{2+}$ responses that were shorter in duration. Most apparent was sharp decay of the mGluR1b mediated $\mathrm{Ca}^{2+}$ responses compared to the responses elicited by mGluR $1 \mathrm{a}$ activation. In functional tests of the cell co-expressing both variants the expected presence of mGluR1a homodimers would discount the data. For this reason we used subunit with point mutation F781P known to prevent G-protein activation (mGluR1aF/P). This mutation is positioned within the third intracellular (i3) loop and does not affect other characteristics of the subunit, nor does it affect Gprotein activation by the adjacent subunit (Hlavackova et al., 2005). Expression of the mutant mGluR1aF/P led to expression of a receptor that did not elicit functional responses (data not shown). Agonist stimulation of cells expressing mGluR1b together with the mutant mGluR1aF/P resulted in responses resembling those obtained with mGluR1a expressing cells (Fig. 6). This is despite the fact, that mGluR $1 \mathrm{aF} / \mathrm{P}$ subunits do not activate G-proteins and therefore the $\mathrm{Ca}^{2+}$ responses upon quisqualate stimulation have to be mediated via mGluR1b subunit heptahelical domain. We measured interval in which $\mathrm{Ca}^{2+}$ response declines to the $50 \%$ of the maximum measured from the time of the peak in at least 9 cells for each construct. This $50 \%$ decay times for cells expressing mGluR1a were 26.0 $\pm 3.5 \mathrm{~s}$, for cells expressing mGluR1b $18.0 \pm 2.6 \mathrm{~s}$ and for cells expressing mGluR1aF/P + mGluR $1 \mathrm{~b}$ $25.6 \pm 2.7 \mathrm{~s}$. These results were obtained with wild type subunits and data obtained using the Nterminally tagged receptors led to compatible results (data not shown). In order to exclude a possibility that the shape of the responses obtained with cells co-transfected with the mGluR1aF/P + mGluR $1 \mathrm{~b}$ is not plain consequence of the elevated surface expression of mGluR1b we used yet another approach. We employed mutated mGluR $1 b$ that is devoid of activation of the VFT. Two amino acids alanine substitution (Y226A and D318A) in the second lobe of VFT of mGluR1b led to quisqualateinsensitive receptors (data not shown). Corresponding YADA mutant was described previously for mGluR5 (Kniazeff et al., 2004). Combination of the mGluR1aF/P + YADA mGluR1b resulted in formation of heterodimers that gave functional responses upon $10 \mu \mathrm{M}$ quisqualate stimulation. These responses were of lower magnitude compared the mGluR $1 \mathrm{aF} / \mathrm{P}+$ mGluR $1 \mathrm{~b}$ combination. This was expected as in the dimeric mGlu receptors both VFTs have to be in closed agonist-bound state in order to elicit maximal response (Kniazeff et al., 2004). This is impossible for the YADA mutant in the agonist concentrations used here. The response to agonist stimulation in such heterodimer is therefore transmitted from conformational change of the mGluR1aF/P VFT on heptahelical domain of 
YADAmGluR1b in trans-activation manner. In other words to elicit functional responses the receptor complexes have to include both splice variants.

Next set of experiments was done with chimeras between GABAb receptors and carboxyl-termini of the mGluR1 variants. In this receptor, extracellular domains and heptahelical domains of two subunits GB1 and GB2 have to assemble to form a functional receptor complex (Jones et al., 1998; Kaupmann et al., 1998; White et al., 1998). The C-termini are not crucial for G-protein activation by GABAb receptor as truncation of these does not prevent coupling to Gi/o pathway (Pagano et al., 2001). We swapped the carboxyl-termini of GB1 and GB2 subunits following their heptahelical domains with the corresponding regions of mGluR1a and mGluR1b variants. The inserted mGluR1 C-termini were derived from sequences starting at amino acid position 859 preceding the RRKK motif by 18 residues. This recombination resulted in four chimerical receptors in which subunits GB1 and GB2 carried Ctermini of either mGluR1a or mGluR1b (named GBn/C1x in the text). All the chimerical subunits $\mathrm{GB} 1 / \mathrm{C} 1 \mathrm{a}, \mathrm{GB} 1 / \mathrm{C} 1 \mathrm{~b}, \mathrm{~GB} 2 / \mathrm{C} 1 \mathrm{a}$ and $\mathrm{GB} 2 / \mathrm{C} 1 \mathrm{~b}$ were well expressed. Co-transfection of pairs of the subunits $\mathrm{GB} 1 / \mathrm{C} 1 \mathrm{a}+\mathrm{GB} 2 / \mathrm{C} 1 \mathrm{a}, \mathrm{GB} 1 / \mathrm{C} 1 \mathrm{a}+\mathrm{GB} 1 / \mathrm{C} 1 \mathrm{~b}$ and $\mathrm{GB} 1 / \mathrm{C} 1 \mathrm{~b}+\mathrm{GB} 2 / \mathrm{C} 1 \mathrm{a}$ resulted in functional receptors measured as IP accumulation upon co-transfection with a chimerical adaptor G-protein Gqi upon agonist stimulation (Fig. 7.a). Co-expression of the pair GB1/C1b+ GB2/C1b in which both Ctermini sequences correspond to mGluR $1 \mathrm{~b}$ resulted in proteins that were retained intracellularly and cells expressing this combination were not responsive to agonist stimulation (Fig. 7b). The relative cell surface expression levels of these recombinant receptors were measured by ELISA in single transfections and co-transfections. Quantification of relative cell surface expression of $\mathrm{GB} 1 / \mathrm{C} 1 \mathrm{~b}$ compared with cell surface targeting of this protein expressed in combination with $\mathrm{GB} 1 / \mathrm{C} 1 \mathrm{a}$ $(\mathrm{GB} 1 / \mathrm{C} 1 \mathrm{a}+\mathrm{GB} 1 / \mathrm{C} 1 \mathrm{~b})$ points on association of the two recombinant proteins and chaperon-like property of the GB1/C1a on the adjacent subunit. Moreover, cell surface expression levels of $\mathrm{GB} 2 / \mathrm{C} 1 \mathrm{~b}$ is substantially enhanced upon co-expression with $\mathrm{GB} 1 / \mathrm{C} 1 \mathrm{a}$ in $\mathrm{GB} 1 / \mathrm{C} 1 \mathrm{a}+\mathrm{GB} 2 / \mathrm{C} 1 \mathrm{~b}$ combination. On the other hand, combination $\mathrm{GB} 1 / \mathrm{C} 1 \mathrm{~b}+\mathrm{GB} 2 / \mathrm{C} 1 \mathrm{~b}$ did not lead to change in cell surface expression of either subunit and co-transfection of HA-mGluR1a did not elevate cell surface expression of Myc-GB2/1b, most likely due to lack of interaction between these proteins (Fig. 7c). 


\section{Discussion}

Our results suggest that long mGluR1a and short mGluR1b variants do combine in functional receptors, even though the portion of the variants that form heterodimers might be minor respective to their total protein pools. We detected large intracellular pools of mGluR1 protein. This is pronounced especially for the mGluR1b while mGluR1a is more readily trafficked to the cell surface. Trafficking of the mGluR1b subunit to the cell surface was strongly enhanced upon co-transfection with mGluR1a. This is of great importance as only the fraction that is trafficked to the surface constitutes functional receptors.

Trafficking of mGluR $1 \mathrm{~b}$ receptor is influenced by presence of RRKK sequence with more apparent consequences than trafficking of the long mGluR1a. Most likely explanation is that the mGluR1a Ctail includes sequence that neutralizes the RRKK motif either directly or it may interact with another protein that masks the basic residues motif (Mary et al., 1998; Remelli et al., 2008). Moreover, our results suggest that within the splice variants heterodimers single copy of the long mGluR1a C-tail may hinder RRKK motive of its own polypeptide chain and also of adjacent subunit that lacks such neutralization sequence.

The RRKK sequence falls into di-lysine motives that are recognized by the coat protein I complex (COPI). For GABAb receptor trafficking similar motif on GB1 is neutralized after dimerization with GB2 C-tail by sterical hindrance upon interactions of their coil-coiled domains. This allows the heterodimer to escape the retrieval of COPI-coated vesicles from cis-Golgi to the endoplasmic reticulum (Brock et al., 2005). The protein 14-3-3 was also reported to play a role in recognition of dimeric membrane proteins, but its role in GABAb receptor trafficking was not proven (Brock et al., 2005). Its eventual role in mGluR1 variants trafficking remains to be elucidated.

Cell surface staining of the mGluR1b subunit was noticeably stronger in cells that co-express both variants compared to cells expressing mGluR1b alone. This observation is in line with results of measurements of presence of mGluR1b on cell surface using ELISA assay. Co-expression of mGluR1a resulted consistently in about 3 -fold increase of the signal detected for mGluR1b compared to its sole expression. Upon co-expression the receptor variants mGluR1a and mGluR1b co-localized at the cell surface. The two splice variants expressed in co-transfected cells co-immunoprecipitate. Moreover, results of HTR-FRET measurements of the cell surface association of the mGluR1a and mGluR1b also suggest on their close association. These results indicate that mGluR1 alternative splice variants that differ within their carboxyl-termini are not devoid of interactions.

The pattern of $\mathrm{Ca}^{2+}$ mobilization upon agonist induced activation was different for both variants. This is in accordance with results from previous studies (Mary et al., 1998; Mary et al., 1997; Pin et al., 1994; Remelli et al., 2008). We used mGluR1a mutant deficient in G-protein coupling (mGluR1aF/P) and co-expressed it with mGluR1b subunit. Because of the lack of G-protein activation by the mGluR1aF/P dimer we did monitor only signaling mediated by the mGluR1b subunit. Theoretically 
this subunit can be either assembled as homodimer, or may heterodimerize with mGluR1aF/P subunit. Shape of the responses to agonist stimulation in cells co-expressing the mGluR1aF/P and mGluR $1 b$ subunits resembled those expressing mGluR $1 \mathrm{a}$ alone. In mGluR $1 \mathrm{aF} / \mathrm{P}+\mathrm{mGluR} 1 \mathrm{~b}$ heterodimers Gprotein activation would be mediated by heptahelical domain of mGluR1b subunit. The responses would thus represent only about half of the theoretical maximum obtained if wild type mGluR1a would be employed. This conclusion we draw based on our previous observations using such mutants (Duthey et al., 2002; Havlickova et al., 2002; Hlavackova et al., 2005). We hypothesize that in the heterodimeric complex the presence of the mGluR1a C-tail is dominant for modulation of the shape of the response. This does not exclude potential existence of other possible variants combinations (mGluR1a+mGluR1a, mGluR1a+mGluR1b, mGluR1b+mGluR1b) at the cell surface. As we could not rule out a possibility that the change of the shape of the response might also be a consequence of higher surface expression of mGluR1b homodimer we employed yet another mutation within mGluR1b subunit. The YADAmGluR1b mutant bears two point mutations within the ligand binding core within the second lobe of the VFT. In functional assay this subunit (or its homodimers) expressed alone is insensitive to $10 \mu \mathrm{M}$ quisqualate treatment. The mGluR1aF/P has ability to bind agonists and its heptahelical domain most likely reaches active conformation upon agonist binding, but this conformational change is not transferred onto G-proteins (Hlavackova et al., 2005). Cells coexpressing the mGluR1aF/P with YADAmGluR1b subunits did respond to agonist stimulation. In such functional heterodimers the two splice variants are therefore present, as the activation of VFT of the mGluR $1 \mathrm{aF} / \mathrm{P}$ has to be transferred on the YADAmGluR1b heptahelical domain to activate Gproteins. It was shown previously, that such trans-activation occurs in mGlu receptors (Brock et al., 2007; Goudet et al., 2005; Hlavackova et al., 2005).

Next we took advantage of the knowledge of the GABAb receptor heterodimerization in experiments aimed to collect further evidence that carboxyl-termini of mGluR1a and mGluR1b do not prevent protein-protein interactions. The GABAb receptor is formed by subunits GB1 and GB2 that have to assemble in functional complexes (Jones et al., 1998; Kaupmann et al., 1998; White et al., 1998). The carboxyl-termini of the GABAb receptor are involved in quality-control of proper heterodimerization but are not mandatory for G-protein coupling (Pagano et al., 2001). Using chimerical GABAb receptor subunits bearing the carboxyl-termini of mGluR1a and mGluR1b splice variants resulted in four GB/mGluR subunits (GB1 or GB2 subunits with either mGluR1a or mGluR1b C-termini). In our previous studies we used chimerical receptors with reverse strategy (Hlavackova et al., 2005; Kniazeff et al., 2004). In these we introduced C-termini of GB1 and GB2 subunits into mGlu receptor subunits with the aim to direct their heterodimerization taking advantage of the dimerization quality-control machinery encoded in those regions. These constructs are trafficked and assembled in comparable manner as are the subunits GB1 and GB2 in the GABAb receptor complexes. This was prerequisite to us for using GABAb receptor assembly in these experiments. 
Co-expression of GB1/C1 and GB2/C1 subunits in which at least one copy of mGluR1a C-tail was present resulted in functional receptors that reach cell surface (combinations GB1/C1a+GB2/C1a, $\mathrm{GB} 1 / \mathrm{C} 1 \mathrm{a}+\mathrm{GB} 2 / \mathrm{C} 1 \mathrm{~b}$ and $\mathrm{GB} 1 / \mathrm{C} 1 \mathrm{~b}+\mathrm{GB} 2 / \mathrm{C} 1 \mathrm{a})$. Heterodimerization of chimerical subunits GB1/C1aGB2/C1b or GB1/C1b-GB2/C1a did occur since the GB1 subunit extracellular N-terminus contains ligand binding site for competitive agonists while G-proteins are activated by adjacent GB2 subunit heptahelical domain. The combination of GB1/mGluR1b+GB2/mGluR1b (in which both subunits bear C-tails of mGluR1b) resulted in expression of subunits that did not reach cell surface. The heptahelical region sequences of our chimerical $\mathrm{GB} / \mathrm{mGluR} 1$ receptors are derived of GABAb receptor and as such they might lack portion of the mGlu receptor that partially neutralizes RRKK motive of the short variant, as mGluR1b is present on cell membrane, even though in lower amounts than mGluR1a. The carboxyl-terminal sequence of mGluR1a contains sequence that neutralizes the RRKK-signal. Our results obtained with the above described GABAb/mGluR chimeras imply that this motive present in at least one copy is able to neutralize two RRKK sequences within the heterodimeric $\mathrm{GB} 1 / \mathrm{C} 1 \mathrm{a}+\mathrm{GB} 2 / \mathrm{C} 1 \mathrm{~b}$ and $\mathrm{GB} 1 / \mathrm{C} 1 \mathrm{~b}+\mathrm{GB} 2 / \mathrm{C} 1 \mathrm{a}$ complexes. As this might be true also for the mGluR1a+mGluR1b dimers, their formation would explain the chaperone effect of mGluR1a on mGluR1b subunit.

Here we show that co-expression of mGluR1a with mGluR1b resulted in enhanced trafficking of mGluR1b to the cell surface and formation of mGluR1a/mGluR1b heterodimers. Two possible mechanisms, not mutually exclusive may cause the chaperone effect of mGluR1a on mGluR1b. The two variants do heterodimerize and presence of single C-tail of mGluR1a within the dimer is sufficient to promote trafficking of the entire complex to the surface. Another potential mechanism would be parallel trafficking of mGluR1b homodimers with mGluR1a homodimers. However, the possibility, that the mGluR1b homodimer surface expression could be driven by mGluR1a homodimer trafficking would require formation of higher-order oligomers, that were not observed for mGlu receptors on cell surface (Brock et al., 2007). It should be stressed out that in this paper receptors on the cell surface were studied and as such this might not reflect a situation in sub cellular fractions in trafficking compartments. In either case it is apparent from our data the fact that carboxyl termini of short and long mGluR1 variants do not prevent protein-protein interactions of their holders.

The carboxyl-termini of mGluR1 are not essential for G-protein activation, but the long and short splice variants modulate differentially receptor signaling properties. Pleiades of proteins associated with GPCRs interact with their carboxyl-terminal tails. Variations in the C-termini of the mGluR1 are reflected not only by the differential functional properties of the receptors, but also by their ability to interact with distinct partner proteins. The chaperon-like performance of the mGluRla toward the short mGluR1b variant may play a role in trafficking in sub cellular compartments and may be of transient nature. On the other hand the possibility of existence of heterodimers in which splice variants of mGluR1 receptor combine in neurons would increase the functional variability of the receptors. 


\section{Figures}

Figure 1 Distribution of mGluR1a and mGluR1b variants in transfected HEK293 Cells

Cells were transfected with the mGluR1a or mGluR1b coding plasmids alone (panel a) or together (panel b). Paraformaldehyde-fixed cells transfected with the indicated plasmids were permeabilised (P) or non-Permeabilised (NP) and stained with rabbit anti-HA (for HA-mGluR1a) or mouse anti-Cmyc (C-Myc-mGluR1b) antibodies and visualized with corresponding secondary antibodies labeled with FITC or Cy3 respectively. Staining was analyzed by confocal microscopy with co-localized fluorescence being shown in yellow. Bar equals to $10 \mu \mathrm{m}$ in vivo.

Figure 2 Characterization of the novel antibodies

a) For immunocytochemistry cells were transfected with HA-mGluR1a and stained with monoclonal anti-HA antibodies (secondary antibodies labeled with FITC) and N14 antibodies (secondary anti rabbit antibodies labeled with Cy3). HA-mGluR1b expressing cells were labeled with anti-HA antibodies and guinea pig $\mathrm{O} 13$ antibodies and detected with secondary antibodies (FITC and Cy3, respectively). The overlapping patterns in yellow confirm specificity of the novel antibodies. b) Permeabilised cells were transfected with both wild type mGluR1a and mGluR1b. Receptors were detected using our polyclonal antibodies for mGluR1a (rabbit N14) and for mGluR1b (guinea pig O13) and stained with corresponding labeled with secondary antibodies FITC and Cy3 respectively. Each panel is representative of at least 30 cells. Bar equals to $10 \mu \mathrm{m}$ in vivo.

Figure 3 Cell surface expressions of mGluR1a and mGluR1b receptors in HEK293 cells.

Cells were transfected with plasmids coding either mGluR1a or mGluR1b variants or co-transfected with both variants and analyzed 24 hours later by ELISA. The N-terminally tagged receptors were detected using corresponding antibodies as indicated. In a) both variants were tagged with HA. Signal from cells transfected with mGluR1a variant alone was designated $100 \%$. In b) the HA-mGluR1a and Myc-mGluR1b were used for transfections. Cells were not permeabilised and only accessible tags for the antibody were on population of the receptors at the cell surface. Signal from cells transfected with single splice variant alone were designated $100 \%$ for HA and C-Myc signals Data are shown as means ${ }^{+} /$- S.D. from $n$ experiments, $* \mathrm{p}<0.05$. c) cells were transfected with stable amounts of HAmGluR1a cDNA and increasing amounts of Myc-mGluR1b (from left $0 \mu \mathrm{g} ; 0.025 \mu \mathrm{g} ; 0.05 \mu \mathrm{g}$; $0.75 \mu \mathrm{g} 0.1 \mu \mathrm{g})$. In left panel total and cell surface detected signal of HA-mGluR1a shows little variation, while progressively increasing amounts of Myc-mGluR1b result in its higher total and cell surface expression as shown in right. Co-transfection of HA-mGluR1a with GABAb subunit MycGB2 was used as a negative control for FRET experiment (see Fig. 4) and did not significantly influence expression or trafficking of HA-mGluR1a. Data are shown as means ${ }^{+} /-$S.D. from $n$ experiments; Cps: counts per second. 
Figure 4 FRET analysis of mGluR1a-mGluR1b association on the cell surface

HTR-FRET signal obtained when co-expressing HA-mGluR1a and C-Myc-mGluR1b. Cells were incubated with both anti-HA antibodies conjugated to the $\mathrm{Eu}^{3+}$ Cryptate donor fluorophore and the anti-C-Myc antibody conjugated to the AlexaFluor 647 acceptor fluorophore. Increasing amounts $(0$, $0.025,0.05$ and $0.075 \mu \mathrm{g}$ per well) of cDNA coding for mGluR1b were transfected and the corresponding FRET signal increased in parallel. In contrast a high amount ( 0.1 microgram) of cDNA coding for GABAb receptor Myc-GB2 subunit leading to a high expression did not give any significant FRET signal with HA-mGluR1a. The data are normalized according to the cell surface expression of mGluR1a.

Data are shown as means ${ }^{+} /-$S.D. from 3 experiments.

Figure 5 Immunoblotts and immuno co-precipitation of mGluR1 splice variants

a) Protein extracts from mock transfected cells (MOCK) and transfected cells with the indicated plasmids were separated by SDS-PAGE. The indicated subunit-specific antibodies were used for staining. b) Enlargement of upper portions of the immunoblots in which additional bands were detected in cells co-expressing mGluR1a and mGluR1b. Appearance of this band was apparent, nevertheless not consistent between experiments (see text for more details). c) The anti-mGluR1b variant specific antibodies were used for immunoprecipitation of proteins from detergent soluble fraction of cells co-expressing both subunits together (lines $\mathrm{AB}$ ) or equivalent of mixture from cells expressing the variants in separate single transfections and mixed consequently (Lines A+B). IP: Antibodies used for precipitation O13 (anti-mGluR1b), Stain: antibodies used for immunodetection Anti-HA labeled with peroxidase, $b$ : bound=immunoprecipitated fraction, $\mathrm{u}$ : unbound=supernatant after precipitation.

Figure 6 Calcium responses mediated by mGluR1a, mGluR1b, mGluR1aF/P+mGluR1b and mGluR1aF/P+YADAmGluR1b. Functional analyzes upon activation of HEK 293 transfected with the indicated plasmids were performed $24 \mathrm{~h}$ after transfection perfused with Fluo-4 AM and stimulated with $10 \mathrm{mM}$ quisqualate. Cells expressing mGluR1a F/P YADAmGluR1b alone did not evoke any responses (data not shown).

Figure 7 Heterodimerization of GABAb receptor subunits GB1 and GB2 bearing carboxy-termini of mGluR1 variants. a) Stimulation of chimerical Gqi protein measured as inositol phosphate accumulation in cells transfected with indicated combinations of GB1 and GB2 subunits in which Ctermini were swapped with those of mGluR1a or mGluR1b. IP accumulation for GB1/mGluR1a+GB2/mGluR1a was arbitrary assigned $100 \%$. The feature of mandatory GABAb subunit heterodimerization for activation of G-proteins implies that subunits bearing different C- 
termini did heterodimerize (see text for more details). b) Non-permeabilised cell expressing the indicated N-terminally tagged constructs detected with anti-HA antibodies. The C-terminal tail of mGluR1a in at least one subunit allowed the receptor complex to reach the surface. Carboxy-terminal tail of mGluR1b receptor in both GABAb receptor subunits caused retention in of the proteins inside the cells. Bar equals to $10 \mu \mathrm{m}$ in vivo. c) Cells were transfected with plasmids coding indicated recombinant proteins alone or co-transfected as labeled and analyzed 24 hours later by ELISA. Relative levels of corresponding signals detected on non-permeabilised cells are shown. Data are shown as means $+/$ S.D. from $n=4$ experiments. ${ }^{*} P<0.05$ 
This work was supported by grants GACR 204/05/0920, GACR303/08/1591 from Czech Science Foundation, GAAV 500390701 from Grant Agency of Academy of Science of the Czech Republic; project LC 06063 of Ministry of Education of the Czech Republic and project "Synscaff" of $6^{\text {th }} \mathrm{FW}$ EC (LSHM-CT-2004-511915) and ASCR-INSERM exchange program. We thank Vladimir Korinek and Ladislav Andera (Institute of Molecular Genetics ASCR) for providing us with the anti-tag antibodies, Ondrej Horvat, David Stanek and Martina Huranova for help with microscopy. Animals were hosted and immunized and the sera prepared in BioTest 1.t.d.. HTR-FRET technology was kindly provided by Cis Bio International. 


\section{Referecences}

Ango, F., Pin, J. P., Tu, J. C., Xiao, B., Worley, P. F., Bockaert, J., Fagni, L., 2000. Dendritic and axonal targeting of type 5 metabotropic glutamate receptor is regulated by homer1 proteins and neuronal excitation. J Neurosci 20, 8710-8716.

Bockaert, J., Marin, P., Dumuis, A., Fagni, L., 2003. The 'magic tail' of G protein-coupled receptors: an anchorage for functional protein networks. FEBS Lett 546, 65-72.

Brock, C., Boudier, L., Maurel, D., Blahos, J., Pin, J. P., 2005. Assembly-dependent surface targeting of the heterodimeric GABAB Receptor is controlled by COPI but not 14-3-3. Mol Biol Cell 16, 5572-5578.

Brock, C., Oueslati, N., Soler, S., Boudier, L., Rondard, P., Pin, J. P., 2007. Activation of a dimeric metabotropic glutamate receptor by intersubunit rearrangement. J Biol Chem 282, 33000-33008.

Ciruela, F., Soloviev, M. M., McIlhinney, R. A., 1999. Cell surface expression of the metabotropic glutamate receptor type 1alpha is regulated by the C-terminal tail. FEBS Lett 448, 91-94.

Conklin, B. R., Farfel, Z., Lustig, K. D., Julius, D., Bourne, H. R., 1993. Substitution of three amino acids switches receptor specificity of Gq alpha to that of Gi alpha. Nature 363, 274276.

Das, S. S., Banker, G. A., 2006. The role of protein interaction motifs in regulating the polarity and clustering of the metabotropic glutamate receptor mGluR1a. J Neurosci 26, 81158125.

Duthey, B., Caudron, S., Perroy, J., Bettler, B., Fagni, L., Pin, J. P., Prezeau, L., 2002. A single subunit (GB2) is required for G-protein activation by the heterodimeric GABA(B) receptor. J Biol Chem 277, 3236-3241.

Francesconi, A., Duvoisin, R. M., 2002. Alternative splicing unmasks dendritic and axonal targeting signals in metabotropic glutamate receptor 1. J Neurosci 22, 2196-2205.

Franek, M., Pagano, A., Kaupmann, K., Bettler, B., Pin, J. P., Blahos, J., 1999. The heteromeric GABA-B receptor recognizes G-protein alpha subunit C-termini. Neuropharmacology 38, 1657-1666.

Galvez, T., Duthey, B., Kniazeff, J., Blahos, J., Rovelli, G., Bettler, B., Prezeau, L., Pin, J. P., 2001. Allosteric interactions between GB1 and GB2 subunits are required for optimal GABA(B) receptor function. EMBO J 20, 2152-2159.

Goudet, C., Kniazeff, J., Hlavackova, V., Malhaire, F., Maurel, D., Acher, F., Blahos, J., Prezeau, L., Pin, J. P., 2005. Asymmetric functioning of dimeric metabotropic glutamate receptors disclosed by positive allosteric modulators. J Biol Chem 280, 24380-24385.

Havlickova, M., Blahos, J., Brabet, I., Liu, J., Hruskova, B., Prezeau, L., Pin, J. P., 2003. The second intracellular loop of metabotropic glutamate receptors recognizes $\mathrm{C}$ termini of Gprotein alpha-subunits. J Biol Chem 278, 35063-35070.

Havlickova, M., Prezeau, L., Duthey, B., Bettler, B., Pin, J. P., Blahos, J., 2002. The intracellular loops of the GB2 subunit are crucial for G-protein coupling of the heteromeric gamma-aminobutyrate B receptor. Mol Pharmacol 62, 343-350.

Hlavackova, V., Goudet, C., Kniazeff, J., Zikova, A., Maurel, D., Vol, C., Trojanova, J., Prezeau, L., Pin, J. P., Blahos, J., 2005. Evidence for a single heptahelical domain being turned on upon activation of a dimeric GPCR. EMBO J 24, 499-509.

Jones, K. A., Borowsky, B., Tamm, J. A., Craig, D. A., Durkin, M. M., Dai, M., Yao, W. J., Johnson, M., Gunwaldsen, C., Huang, L. Y., Tang, C., Shen, Q., Salon, J. A., Morse, K., Laz, T., Smith, K. E., Nagarathnam, D., Noble, S. A., Branchek, T. A., Gerald, C., 1998. 
$\mathrm{GABA}(\mathrm{B})$ receptors function as a heteromeric assembly of the subunits $\mathrm{GABA}(\mathrm{B}) \mathrm{R} 1$ and GABA(B)R2. Nature 396, 674-679.

Kaupmann, K., Malitschek, B., Schuler, V., Heid, J., Froestl, W., Beck, P., Mosbacher, J., Bischoff, S., Kulik, A., Shigemoto, R., Karschin, A., Bettler, B., 1998. GABA(B)-receptor subtypes assemble into functional heteromeric complexes. Nature 396, 683-687.

Kim, C. H., Lee, J., Lee, J. Y., Roche, K. W., 2008. Metabotropic glutamate receptors: phosphorylation and receptor signaling. J Neurosci Res 86, 1-10.

Kniazeff, J., Bessis, A. S., Maurel, D., Ansanay, H., Prezeau, L., Pin, J. P., 2004. Closed state of both binding domains of homodimeric mGlu receptors is required for full activity. Nat Struct Mol Biol 11, 706-713.

Laemmli, U. K., 1970. Cleavage of structural proteins during the assembly of the head of bacteriophage T4. Nature 227, 680-685.

Mary, S., Gomeza, J., Prezeau, L., Bockaert, J., Pin, J. P., 1998. A cluster of basic residues in the carboxyl-terminal tail of the short metabotropic glutamate receptor 1 variants impairs their coupling to phospholipase C. J Biol Chem 273, 425-432.

Mary, S., Stephan, D., Gomeza, J., Bockaert, J., Pruss, R. M., Pin, J. P., 1997. The rat mGluR1d receptor splice variant shares functional properties with the other short isoforms of mGluR1 receptor. Eur J Pharmacol 335, 65-72.

Mateos, J. M., Azkue, J., Benitez, R., Sarria, R., Losada, J., Conquet, F., Ferraguti, F., Kuhn, R., Knopfel, T., Grandes, P., 1998. Immunocytochemical localization of the mGluR1b metabotropic glutamate receptor in the rat hypothalamus. J Comp Neurol 390, 225-233.

Maurel, D., Kniazeff, J., Mathis, G., Trinquet, E., Pin, J. P., Ansanay, H., 2004. Cell surface detection of membrane protein interaction with homogeneous time-resolved fluorescence resonance energy transfer technology. Anal Biochem 329, 253-262.

Mundell, S. J., Pula, G., McIlhinney, R. A., Roberts, P. J., Kelly, E., 2004. Desensitization and internalization of metabotropic glutamate receptor 1 a following activation of heterologous Gq/11-coupled receptors. Biochemistry 43, 7541-7551.

Pagano, A., Rovelli, G., Mosbacher, J., Lohmann, T., Duthey, B., Stauffer, D., Ristig, D., Schuler, V., Meigel, I., Lampert, C., Stein, T., Prezeau, L., Blahos, J., Pin, J., Froestl, W., Kuhn, R., Heid, J., Kaupmann, K., Bettler, B., 2001. C-terminal interaction is essential for surface trafficking but not for heteromeric assembly of GABA(b) receptors. J Neurosci 21, 1189-1202.

Petralia, R. S., Wang, Y. X., Singh, S., Wu, C., Shi, L., Wei, J., Wenthold, R. J., 1997. A monoclonal antibody shows discrete cellular and subcellular localizations of mGluR1 alpha metabotropic glutamate receptors. J Chem Neuroanat 13, 77-93.

Pin, J. P., Duvoisin, R., 1995. The metabotropic glutamate receptors: structure and functions. Neuropharmacology 34, 1-26.

Pin, J. P., Joly, C., Heinemann, S. F., Bockaert, J., 1994. Domains involved in the specificity of $\mathrm{G}$ protein activation in phospholipase $\mathrm{C}$-coupled metabotropic glutamate receptors. EMBO J 13, 342-348.

Pin, J. P., Waeber, C., Prezeau, L., Bockaert, J., Heinemann, S. F., 1992. Alternative splicing generates metabotropic glutamate receptors inducing different patterns of calcium release in Xenopus oocytes. Proc Natl Acad Sci U S A 89, 10331-10335.

Prezeau, L., Gomeza, J., Ahern, S., Mary, S., Galvez, T., Bockaert, J., Pin, J. P., 1996. Changes in the carboxyl-terminal domain of metabotropic glutamate receptor 1 by alternative splicing generate receptors with differing agonist-independent activity. Mol Pharmacol 49, 422-429.

Remelli, R., Robbins, M. J., McIlhinney, R. A., 2008. The C-terminus of the metabotropic glutamate receptor $1 \mathrm{~b}$ regulates dimerization of the receptor. J Neurochem 104, 1020-1031. 
Romano, C., Yang, W. L., O'Malley, K. L., 1996. Metabotropic glutamate receptor 5 is a disulfide-linked dimer. J Biol Chem 271, 28612-28616.

Shigemoto, R., Kulik, A., Roberts, J. D., Ohishi, H., Nusser, Z., Kaneko, T., Somogyi, P., 1996. Target-cell-specific concentration of a metabotropic glutamate receptor in the presynaptic active zone. Nature 381, 523-525.

Schagger, H., von Jagow, G., 1987. Tricine-sodium dodecyl sulfate-polyacrylamide gel electrophoresis for the separation of proteins in the range from 1 to $100 \mathrm{kDa}$. Anal Biochem $166,368-379$.

White, J. H., Wise, A., Main, M. J., Green, A., Fraser, N. J., Disney, G. H., Barnes, A. A., Emson, P., Foord, S. M., Marshall, F. H., 1998. Heterodimerization is required for the formation of a functional GABA(B) receptor. Nature 396, 679-682. 
a)

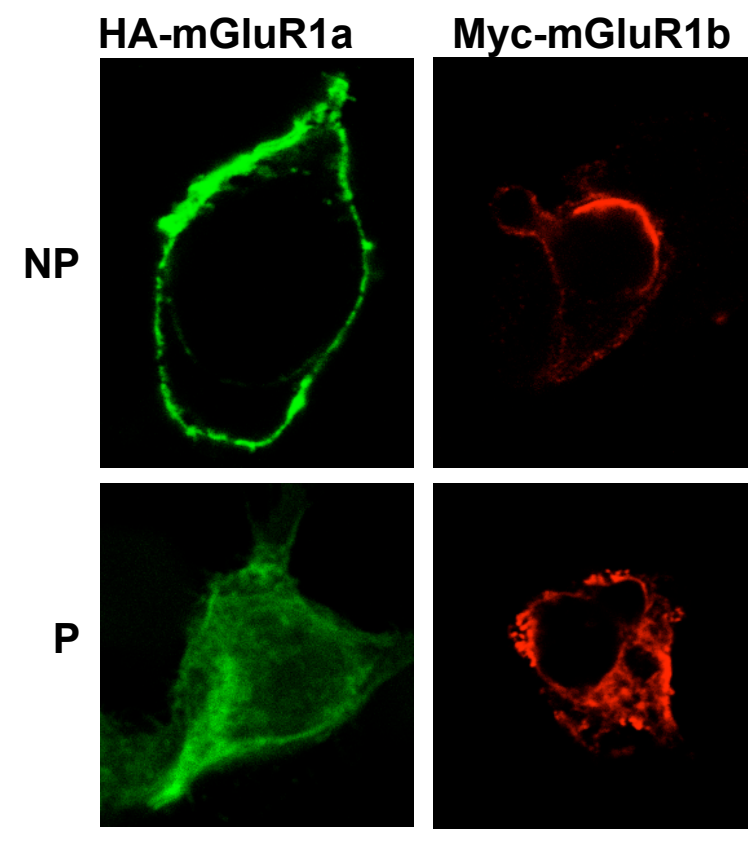

b)

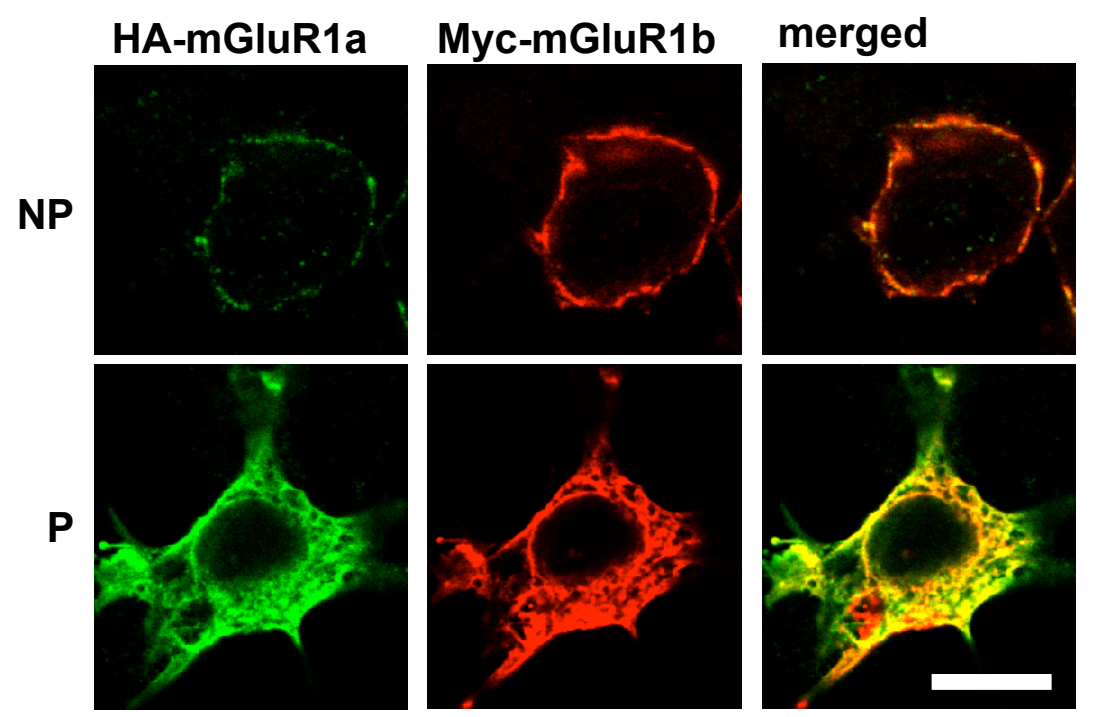

Figure 1 

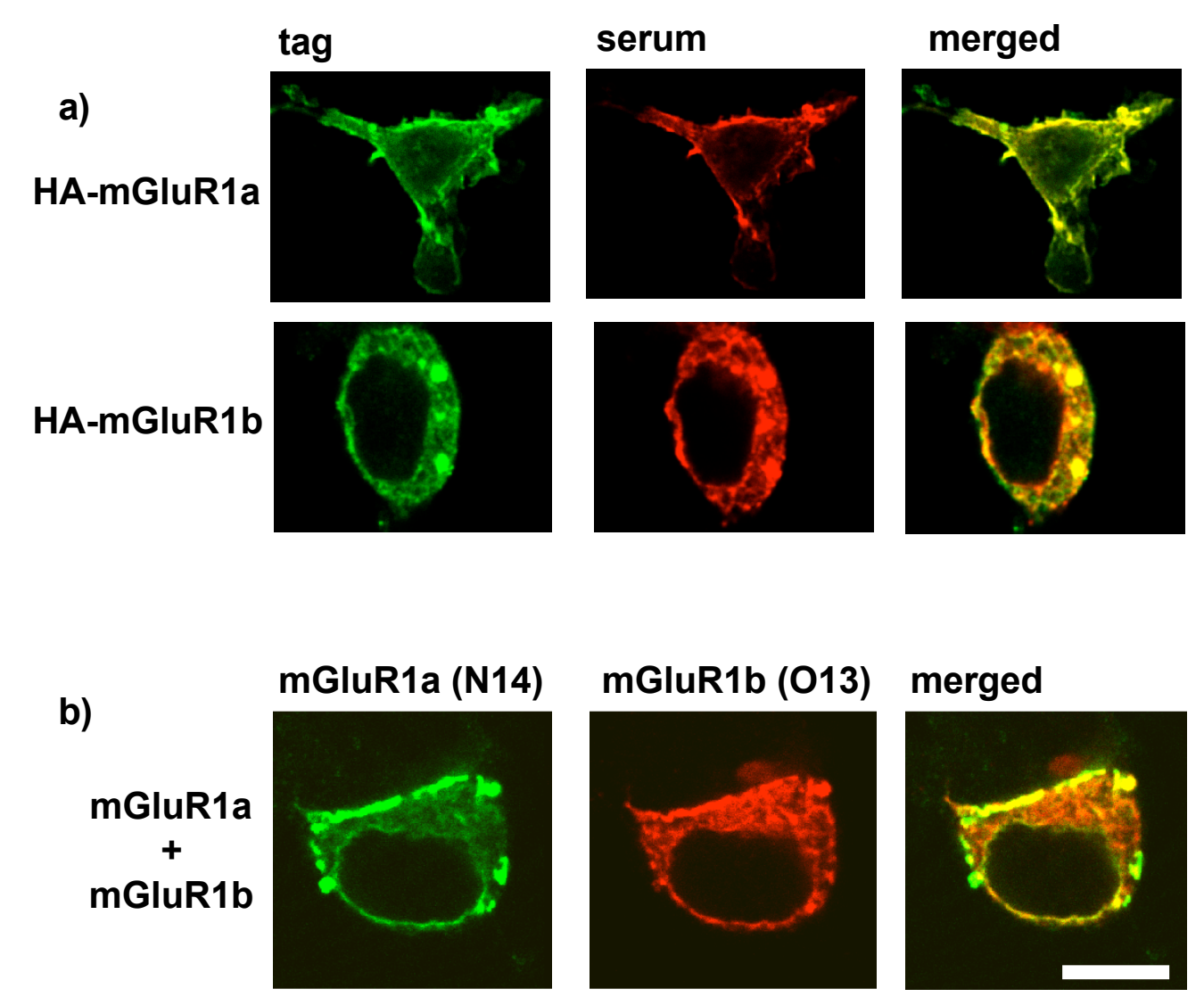
a)

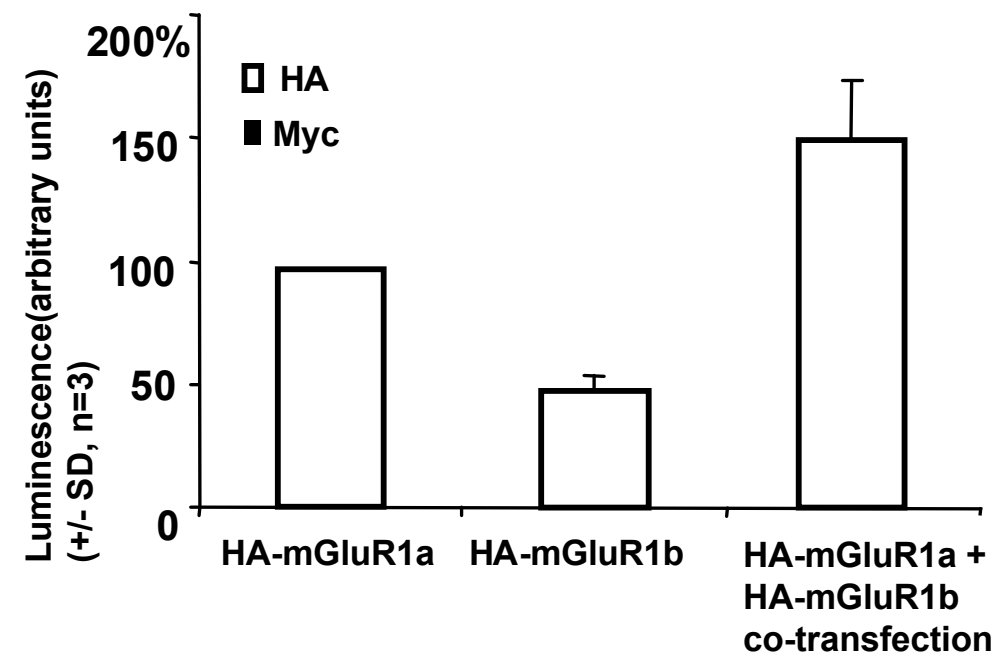

c)

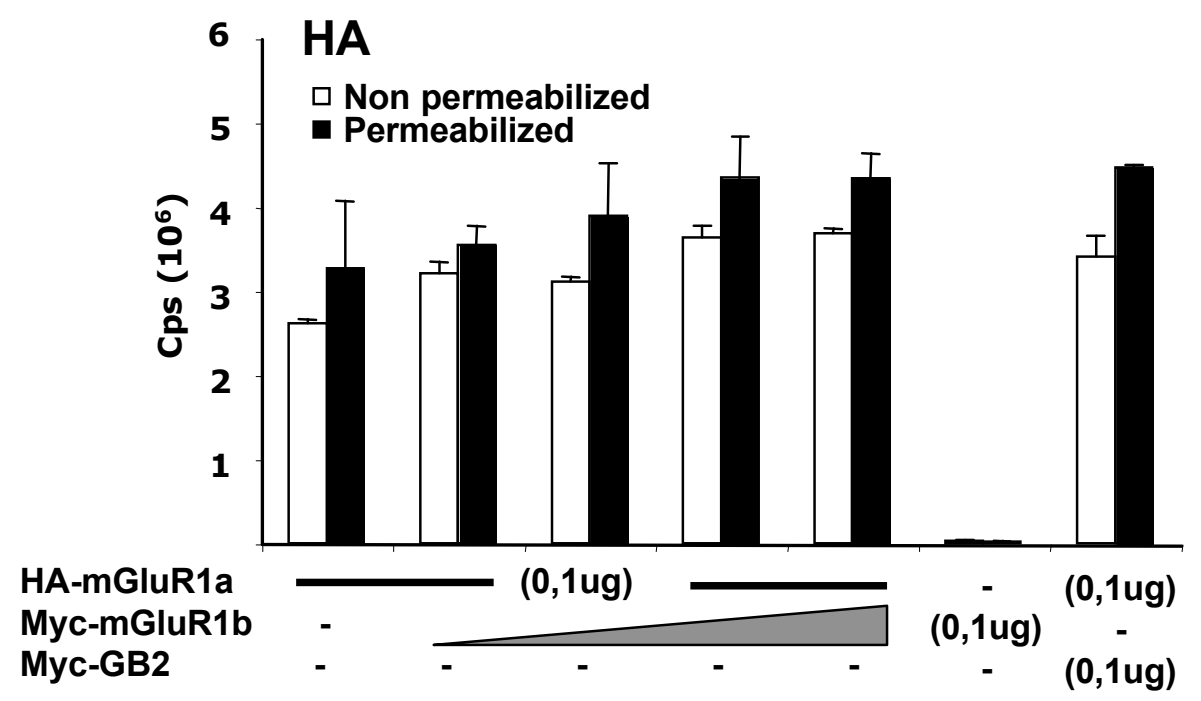

b)
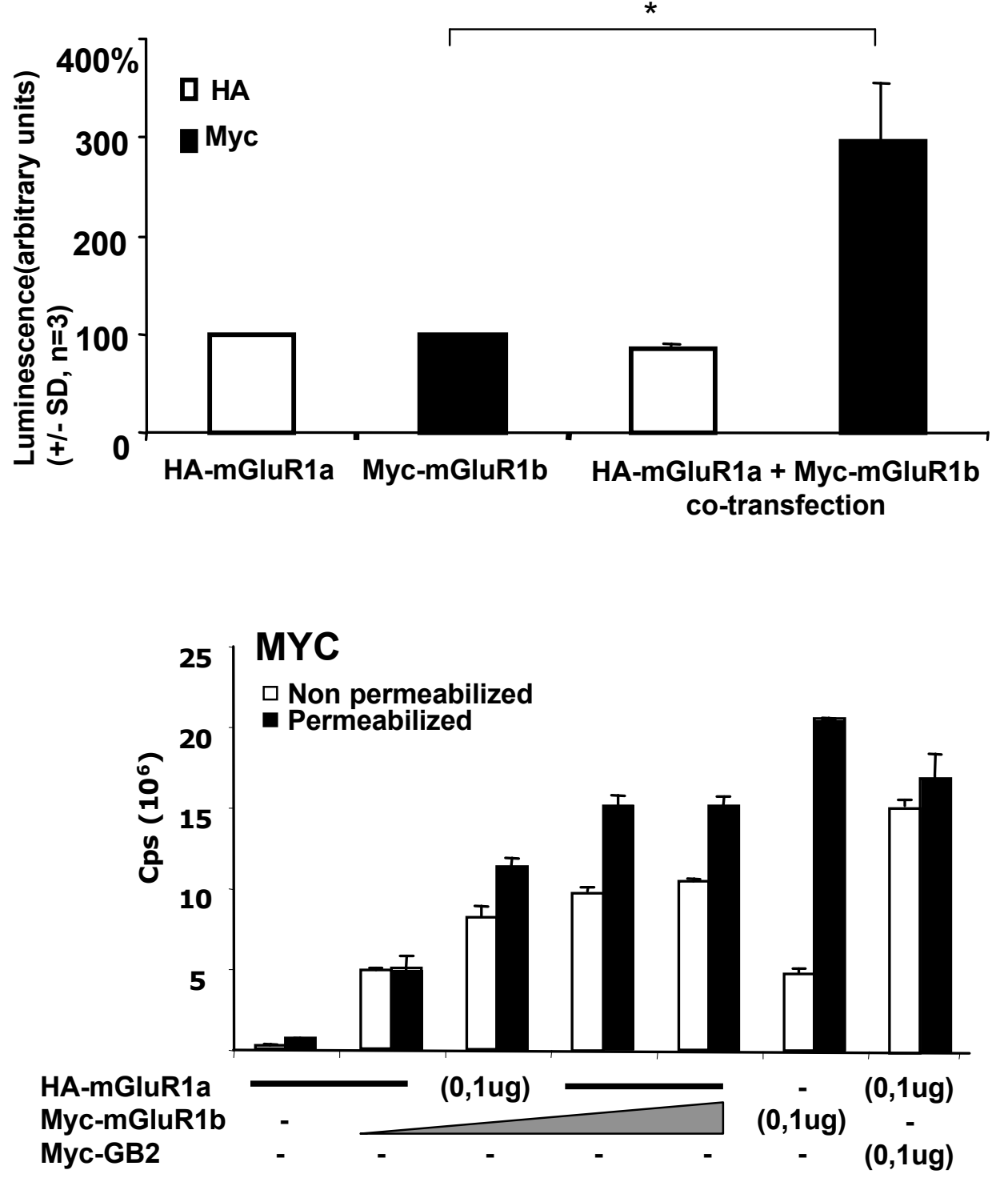

Figure 3 


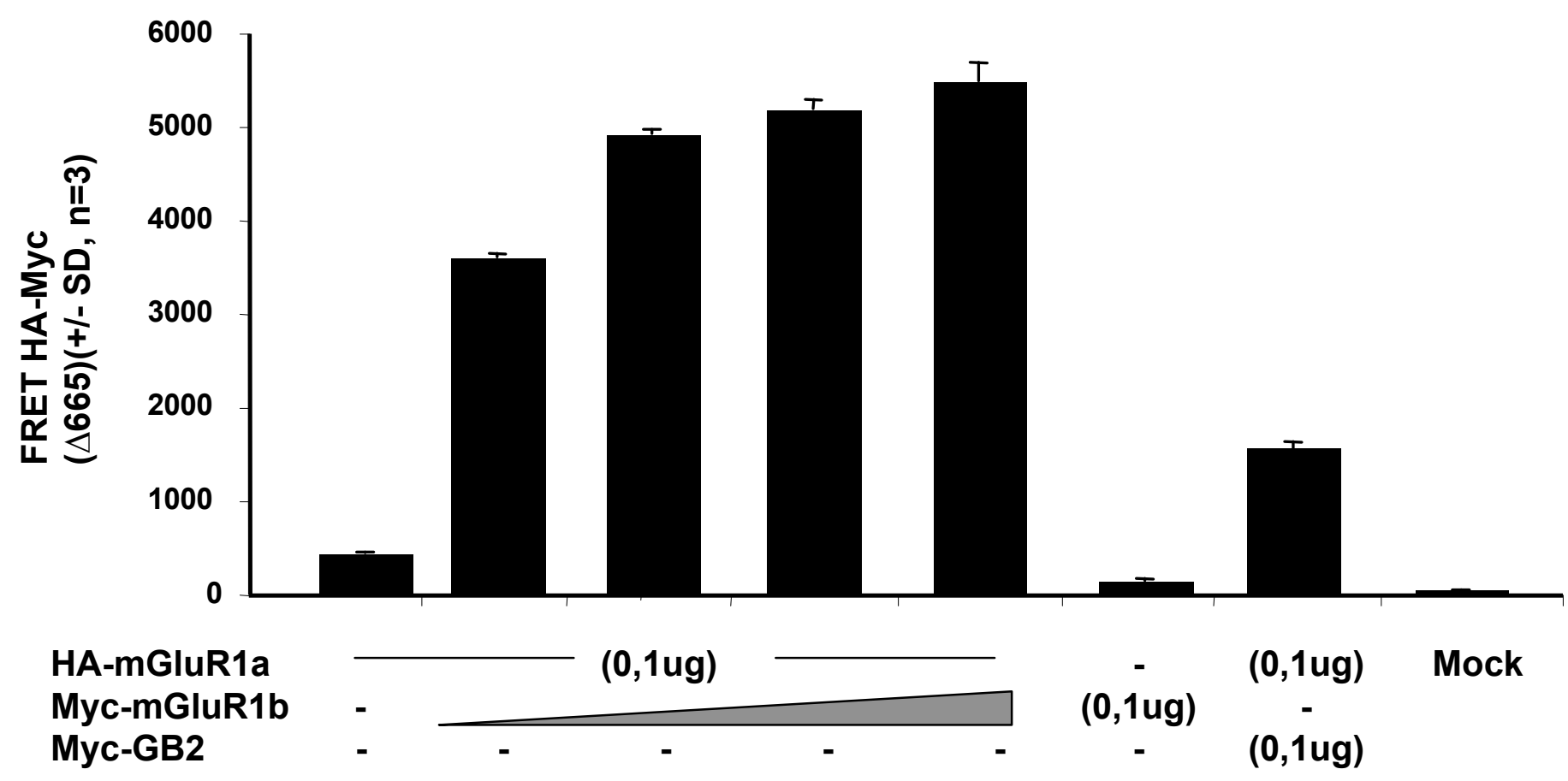

Figure 4 
a)
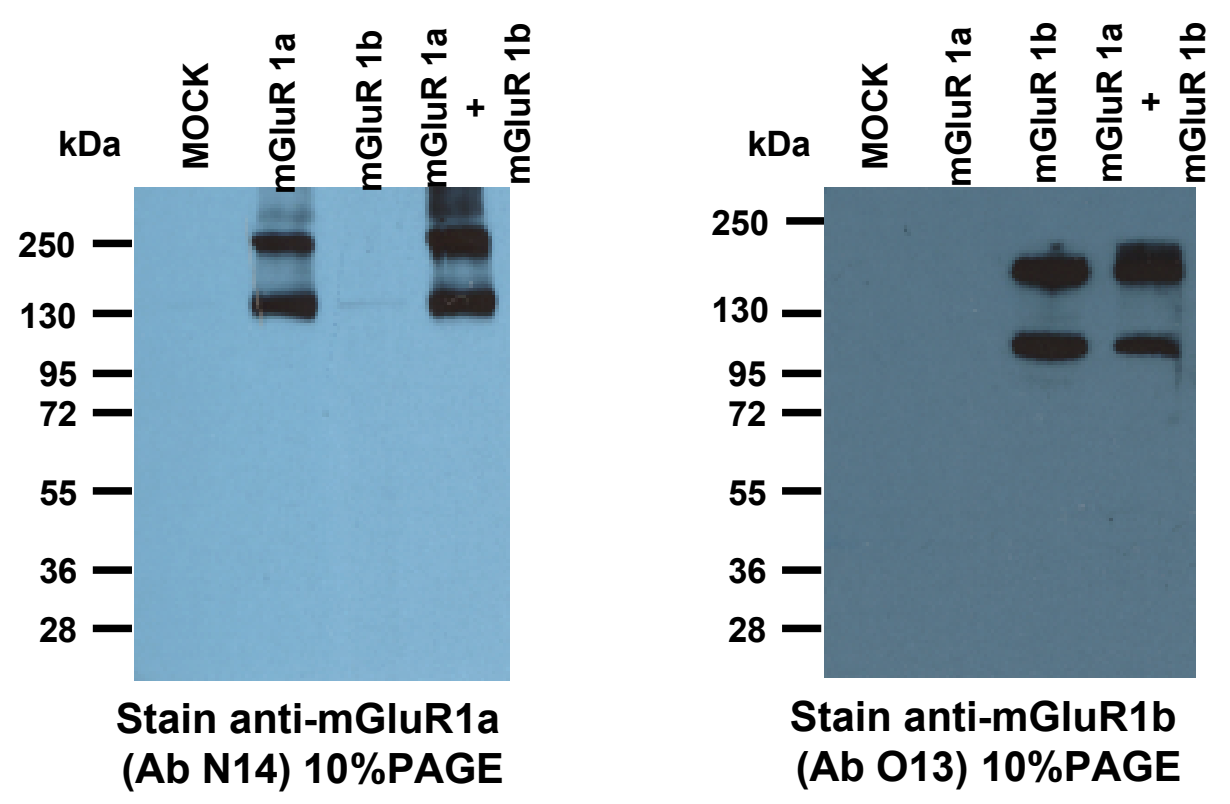

b)

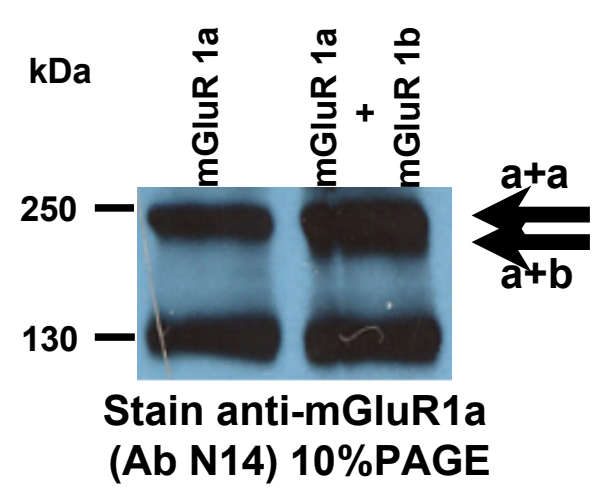

c)

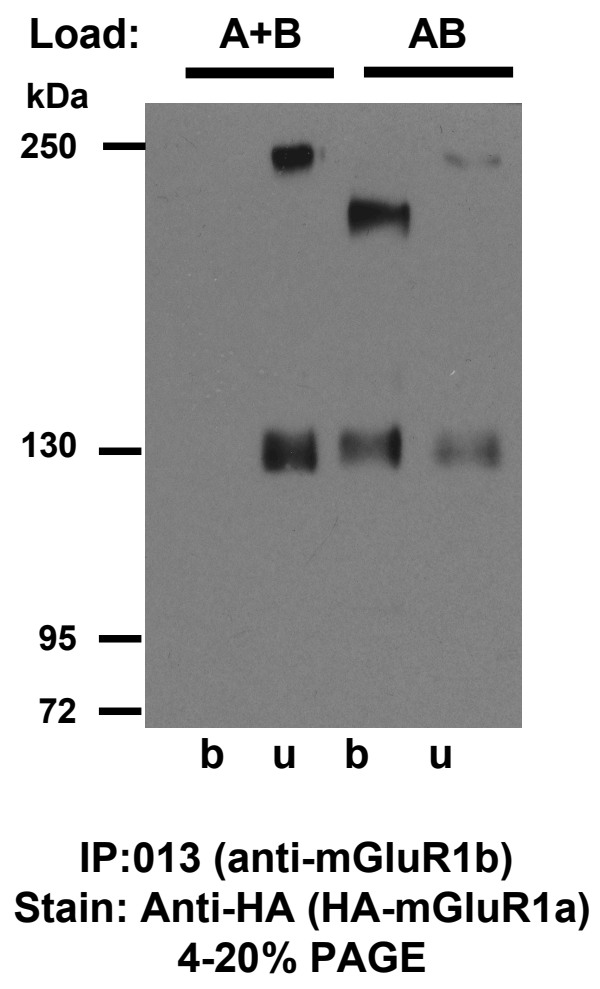

Figure 5

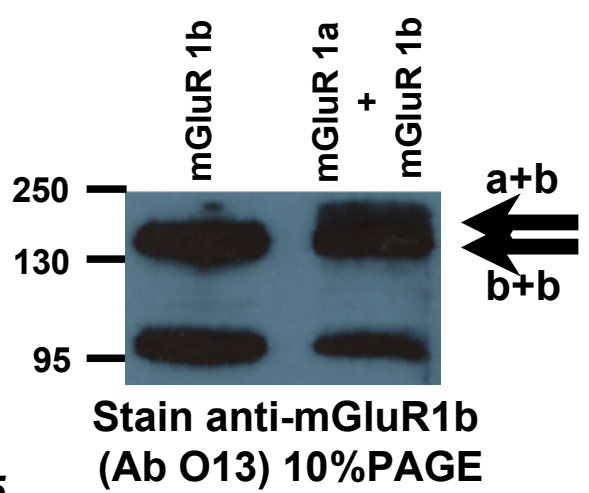

ain: Anti-HA (HA-mGluR1a) 

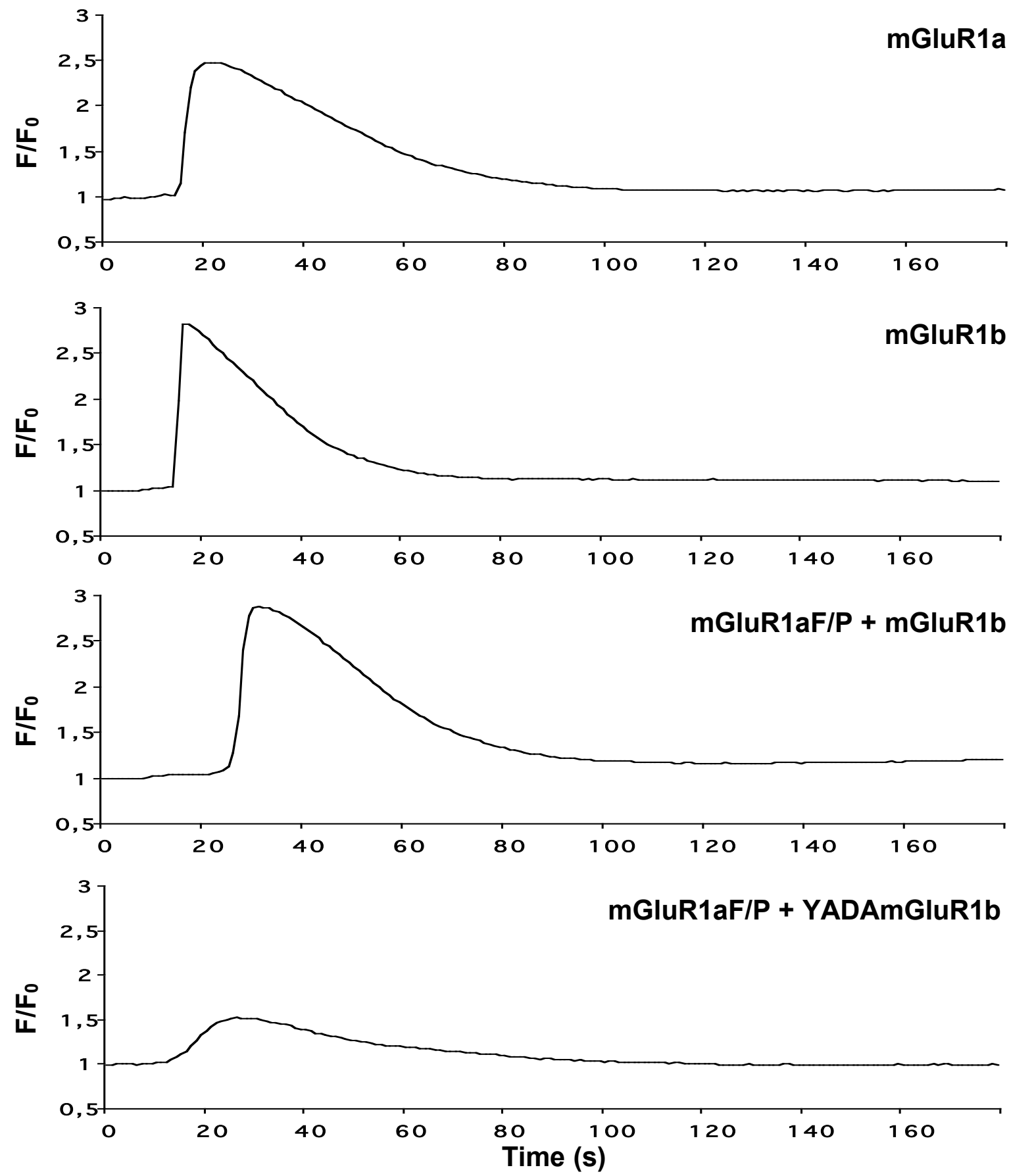

Figure 6 
a)

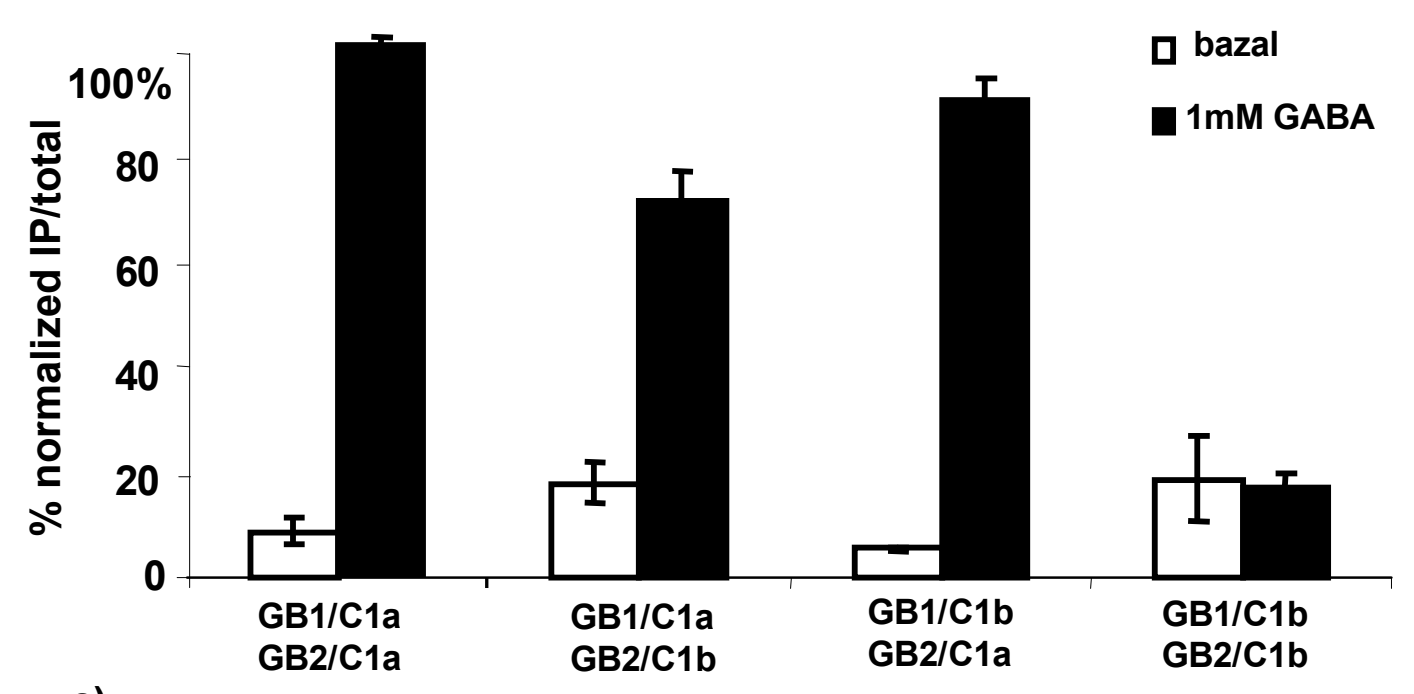

c)

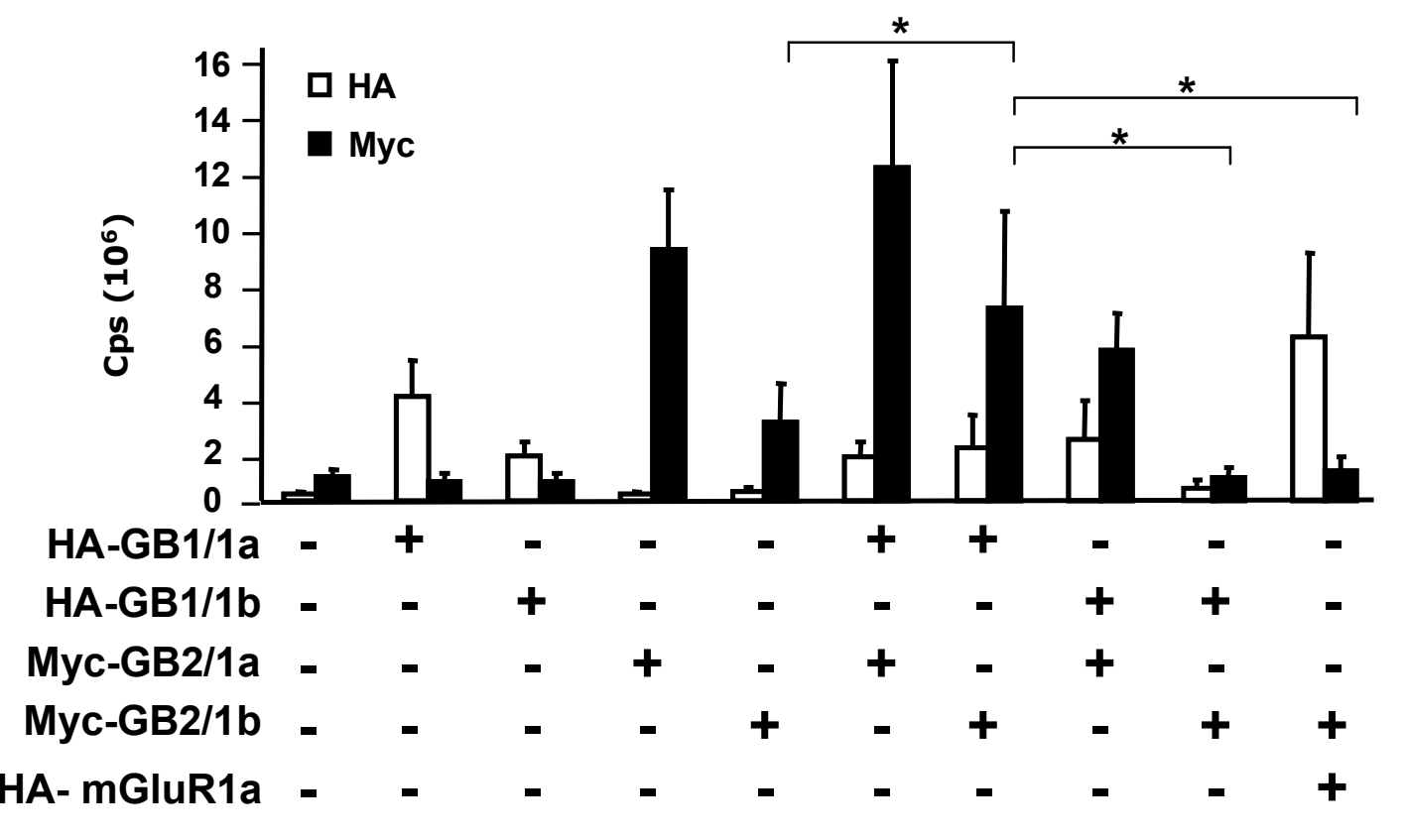

b)

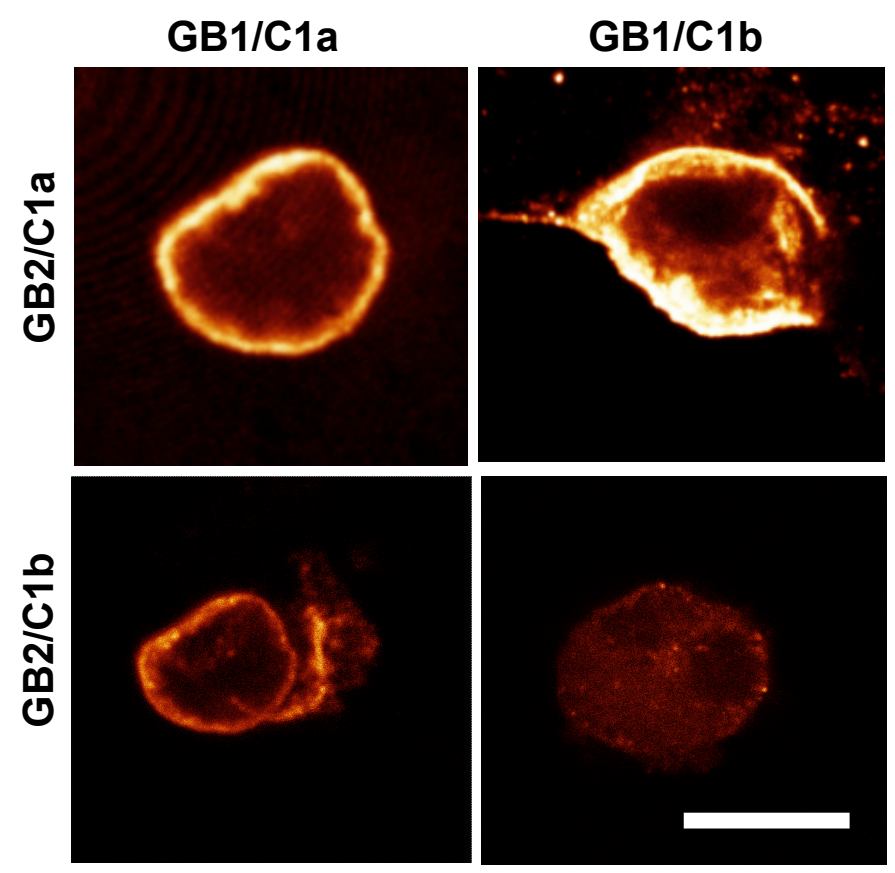

Figure 7 